\title{
A HERNÁD-VÖLGY HONFOGLALÓI. RÉSZLET EGY RÉGIÓ TÖRTÉNETÉBŐL
}

\section{Libor CSILla - TAKáCs RicháRd}

Magyar Régészet 8. évf. (2019), 3. szám, pp. 28-34, https://doi.org/10.36245/mr.2019.3.9

Az utóbbi évtizedben újra nagy lendületet vett a Kárpát-medence 10-11. századi történetének kutatása. Egyre kevesebb a fehér folt ezen idöszakkal kapcsolatban; az újabb ásatások egy-egy kisebb tájegység történetét is megvilágíthatják. Ugyanakkor korántsem ért a végére a kutatás, minden egyes ásatás egyegy újabb mozaikdarabbal járul hozzá a nagy kép egészéhez. Szalaszend egy eddig kevésbé ismert régió, a Hernád-völgy egyik elsö honfoglalás kori lelöhelye, amely nem mezögazdasági munkálatok, hanem ásatás során került a felszínre, ezért számos új információval szolgál a korszak és a régió kutatóinak egyaránt.

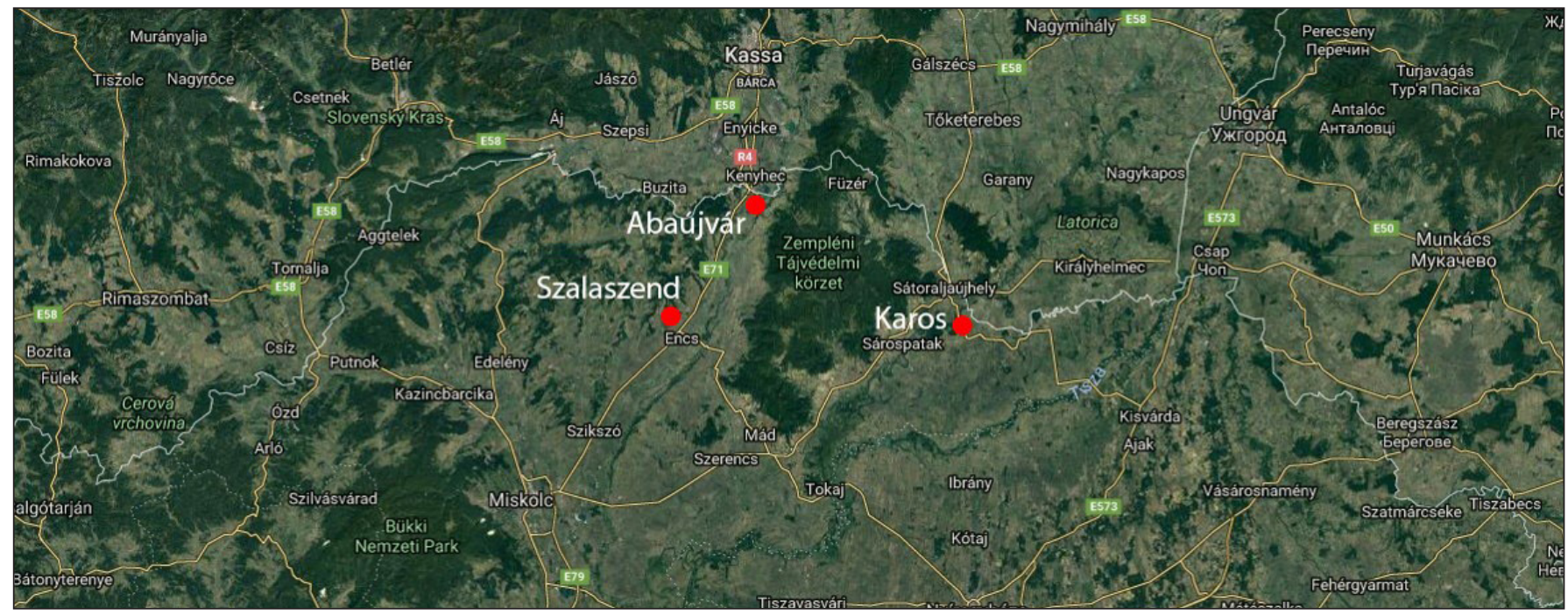

1. kép: Szalaszend elhelyezkedése Borsod megyében

2018 tavaszán kezdődtek meg az M30-as autópálya C üteméhez kapcsolódó megelőző régészeti feltárások (1. kép). Az újonnan megalakult Magyar Nemzeti Múzeum Régészeti és Örökségvédelmi Igazgatósága teljes kapacitással kezdett bele az ásatásokba az épülő út nyomvonalán. Szalaszend - Nagy- és Kishegy nevü lelőhelyen egy bronzkori földvártól délre fekvő területen került elő 2017 őszén az első honfoglalás kori sír. A beruházáshoz kapcsolódó előzetes régészeti dokumentáció elkészítéséhez Pusztai Tamás, a Herman Ottó Múzeum régésze végzett próbafeltárást.

Ezt követöen 2018-ban $22000 \mathrm{~m}^{2}$ területen a 650 bronzkori és vaskori objektum mellett hat honfoglalás kori sírt is találtunk a megelőző feltárás során (2. kép). A lelőhely a Hernád völgyében fekszik, egy magaslaton, melyet ma már a felszínen nem látható vízmosások öveztek (3-4. kép). A 10. századi anyagot csupán ezek a temetkezések képviselték, melyek a fent említett vízmosások egyikének partján helyezkedtek el.

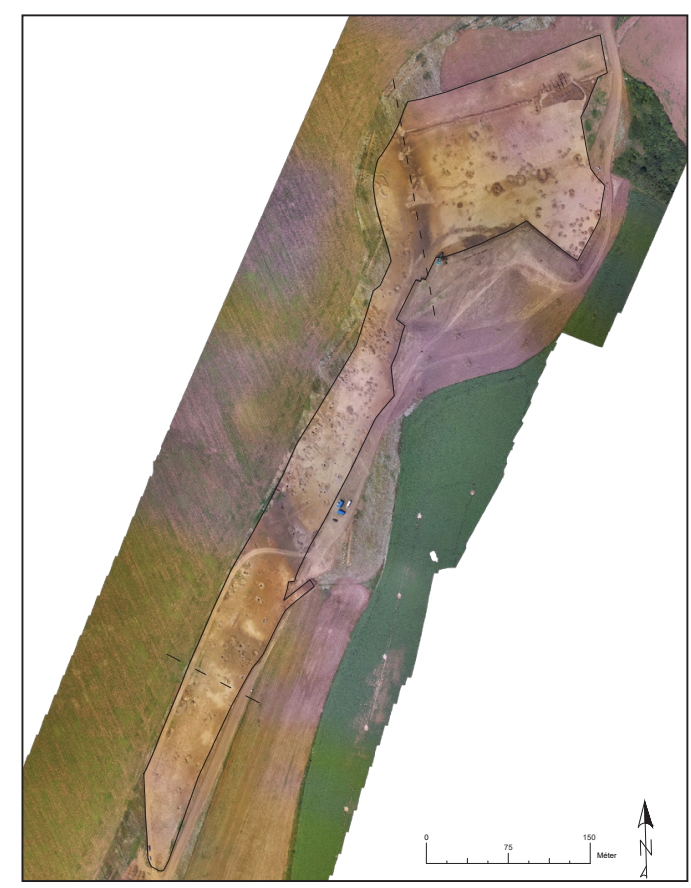

2. kép: A lelöhely felülnézeti ortofotója 
Libor Csilla - Takács Richárd • A Hernád-völgy honfoglalói. Részlet egy régió történetéböl

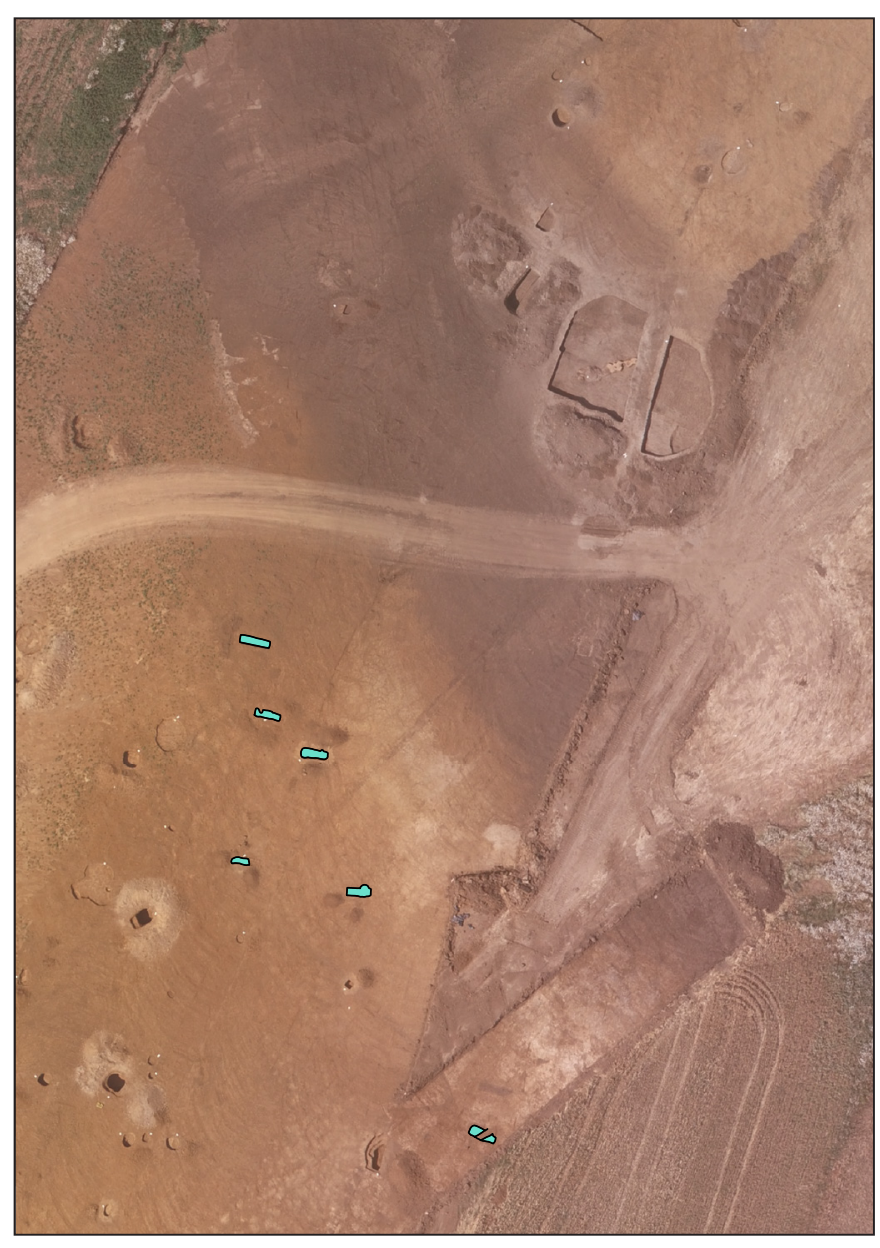

3. kép: A sirok elhelyezkedése a vízmosás mellett

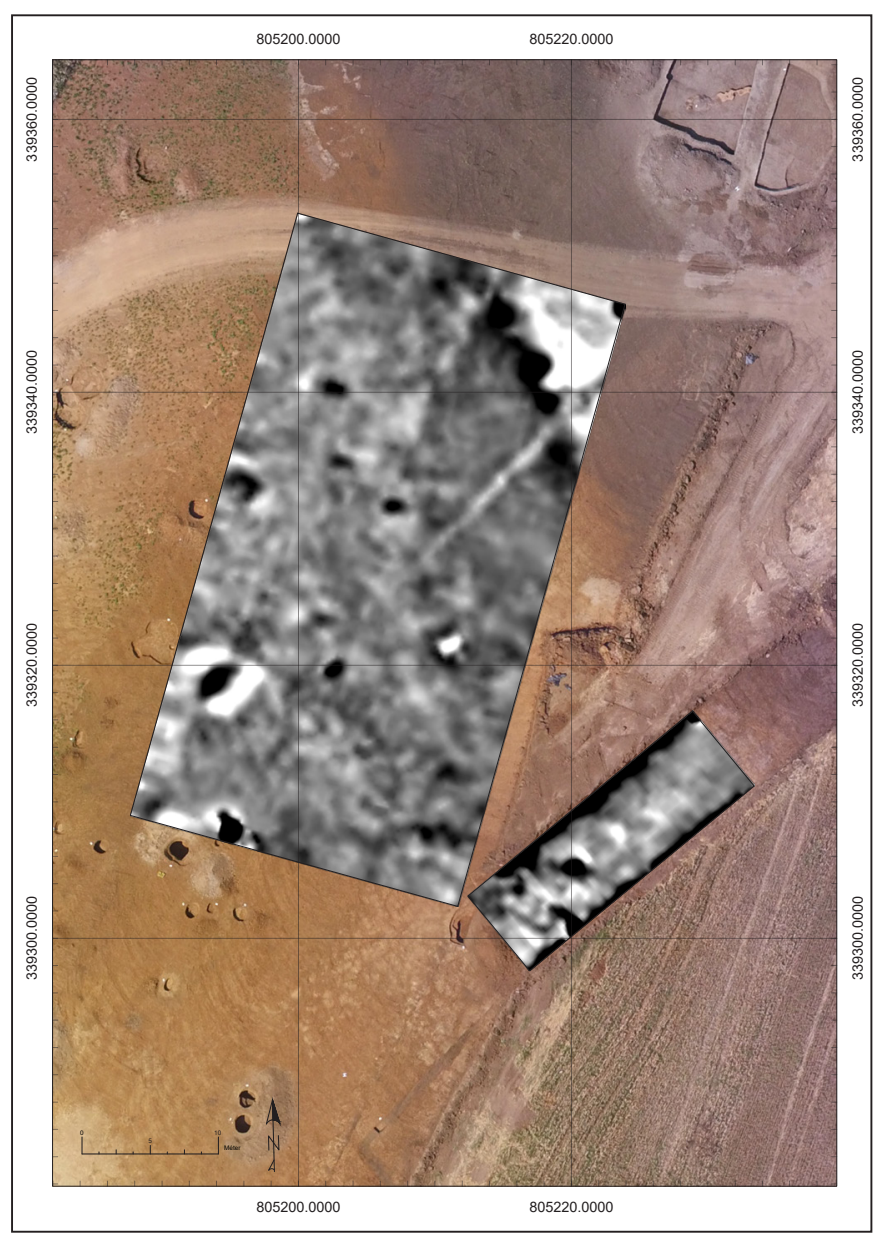

4. kép: A geofizikai mérések eredménye sem mutatott több sirt a területen

\section{TEMETÉSI RITUS}

A Szalaszend Kis- és Nagy-hegyen feltárt 10. századi temetőrészlet temetkezései kelet-nyugati tájolásúak, valamint két sírsorba rendeződnek. A sírok lekerekített téglalap alakúak és viszonylag sekélyek voltak. ${ }^{1}$ A lelőhely értelmezését nehezíti, hogy a sírokat viszonylag hamar kirabolták. Betöltésük majdnem azonos volt az altalajéval. Maguk a sírfoltok nem voltak észrevehetők, csupán a rablógödrök alapján fedeztük fel őket. A rablók célirányosan a felsőtestre ástak rá, ami azt jelenti, hogy a sírjelölések még látszódtak, ám a test már lebomlott, mert a szétdobált csontok között anatómiai kapcsolat már nem volt kivehetö.

\section{LOVASTEMETKEZÉSEK}

A 10. században általánosnak tekinthetők a lovastemetkezések különböző formái a teljes Kárpát-medencében. A tárgyi leletek mellett a szalaszendi sírok közül háromban lócsontokat is találtunk. Az egyik női sírból például egy ló lábszárcsontjai kerültek elö; ez a honfoglalás kori nyúzott lóbőrös temetkezésekre jellemző. A még 2017-ben feltárt 1. sír esetében a lábszárcsontok mellett a ló koponyáját is sikerült megtalálni. Ez azt jelenti, hogy a korszakban szokásos módon a sírba csak a ló koponyája és lábai kerültek a lenyúzott lóbőrrel együtt. A lovak a honfoglaló magyarok lóállományára jellemző, alacsony marmagasságú (körülbelül 138-142 cm magas) egyedek voltak, és a férfi és női temetkezésekben talált lócsontok között nem volt jelentős méretbeli különbség. ${ }^{2}$ Csak a fentebb említett női sír, azaz az S 679 esetében tudtuk megfigyelni a lócsontok pontos helyét: valószínüleg az elhunyt lábaihoz helyezhették. Még egy érdekes részlet ezzel kap-

A lehumuszolt felszíntől számított 3-5 cm mélységben már jelentkeztek a csontok.

2 Az archaeozoológiai vizsgálatot Fekete Fruzsina végezte. Ezúton is szeretnénk neki köszönetet mondani munkájáért. 
Libor Csilla - Takács Richárd • A Hernád-völgy honfoglalói. Részlet egy régió történetéböl

csolatban, hogy az 1. sírban feltárt férfi mellé helyezett ló csontjain erös ízületi gyulladás nyomai láthatóak, ami arra utalhat, hogy ennek a lónak nehezére eshetett a mozgás. Felmerül a kérdés, hogy vajon azért került a sírba, mert a tulajdonos lova volt és így az akkoriban már idősnek számító (maturus, 40-60 év közötti férfi mellé került hasonlóan öreg és beteges lova? Vagy csupán egy ló volt a karámban, aminek már nem vették hasznát, és így a temetkezés során őt áldozták fel?

\section{LÓSZERSZÁMZAT}

Lovas felszerelésre utaló leletek (hevedercsat, zabla, kengyel) több sírból is elökerültek.

A lovas felszerelés egyik legfontosabb eleme a kengyel. Lelöhelyünkön két sírban találtunk ilyen tárgyat. Az S 530-as sírban egy trapéz alakú kengyelt találtunkt (5. kép), míg az S 531-ből egy körte alakú példány látta meg a napvilágot (6. kép). Szintén kengyelként azonosítottuk azt a szórvány is, ami az SNR 530 közelében került elő a szubhumuszból. A töredék feltehetően egy körte alakú kengyelhez tartozhatott.

Érdekes, hogy mindkét sírból csupán egyetlen kengyel került elő. Számolhatunk azzal, hogy már a temetés során is csak egy kengyelt helyeztek a halott mellé, ugyanakkor elképzelhető, hogy a másik kengyel szerves anyagból készült, aminek nem maradt nyoma; esetleg a korabeli bolygatások következtében tünhettek el. Azonban a sírok nagyarányú rablottsága és a viszonylag alacsony sírszám miatt biztos magyarázatot nem adhatunk.

A körte alakú kengyelek a 10. században végig elterjedtek voltak a Kárpát-medencében, így a korszakon belüli pontosabb datálásra alkalmatlanok. A trapéz alakú kengyelek a 10. század középső harmadában jelentek meg (RÉvÉsz, 1996, p. 46), azonban csak a század második felében terjedtek el széles körben (Révész, 1996, p. 45).

A kengyelek belső magassága viszonylag kicsi (105-119 mm között változik). Ennek használata Dienes István (DIENES, 1966, p. 231) és Révész László (RÉvész, 1996, p. 43) egybehangzó véleménye szerint elsősorban a nőkre és a lovaglásban kevésbé jártas, előkelő férfiakra volt jellemző. A szükebb kengyelek biztonságosabbak voltak, ugyanis ha a lovas leesett a lóról, nem akadt be a lába.

A ló irányításának legfontosabb eszköze a zabla. Temetőrészletünkben két sírból kerültek elö; mindkét példány a kétkarikás, csuklós csikózablák közé tartozik. Az S 530-ban egy aszimmetrikus zabla (7. kép), míg az $\mathrm{S}$ 679-ben szimmetrikus szájvasú

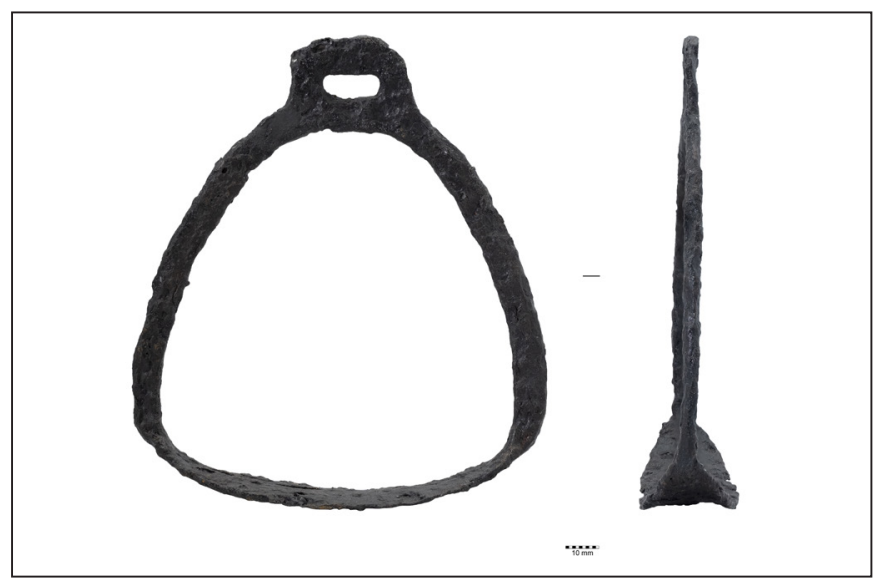

5. kép: Trapéz alakú kengyel az S 530-as sírból

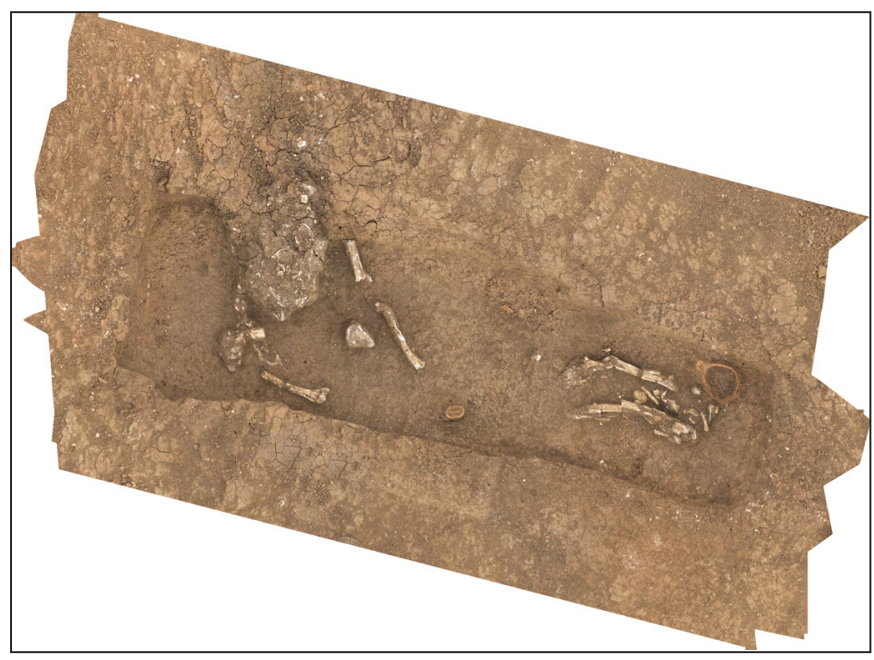

6. kép: Az S 531-es sir ortofotója

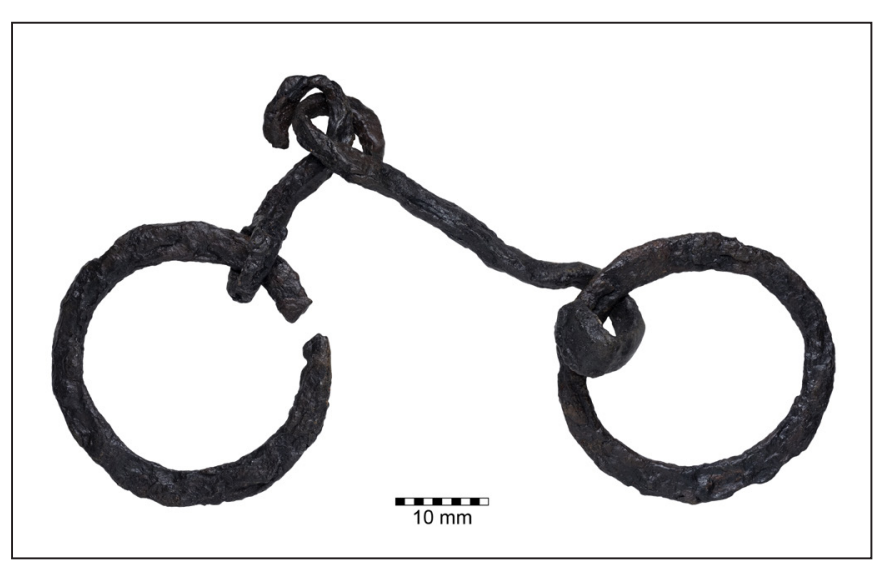

7. kép: Az S 530-as sírból előkerült vas zabla 
Libor Csilla - Takács Richárd • A Hernád-völgy honfoglalói. Részlet egy régió történetéböl

zabla volt. A két típus általánosan elterjedt, pontosabb datálásra nem alkalmasak. A karikák mérete alapján mindkét darab a kiskarikás zablák csoportjába tartozik.

A szimmetrikus szájvasú zablák a lovak könnyebb irányítását tették lehetővé; a szük kengyelekhez hasonlóan ez a zablatípus is a kevésbé gyakorlott lovasok eszköze volt. Az aszimmetrikus szájvasú zablákat a harcosok, pásztorok alkalmazták, akiknek nem volt lehetőségük minden esetben két kézzel tartani a szárat (DiENEs, 1966, p. 220).

A nyereg rögzítésére szolgáló hevedercsatot csak az S 531 tartalmazott. Alakja téglalap, tüskéje hozzákorrodálódott a karikához.

\section{ÉKSZEREK}

A szalaszendi temetőrészlet esetében két sírból kerültek elő ékszerként értelmezhető tárgyak.

A fej ékszereit az S 489 és 679 sírokból napvilágra került karikaékszerek képviselik. Mindkét példány ezüst, kör alakú, nyitott, vékony huzalú (1-2 mm vastag) karikaékszer. Ez a típus a teljes Kárpát-medencében elterjedt volt a 10. században, azonban a század végére kikoptak a divatból, a 11. századra eltüntek (SZÖKE\&VÁNDOR, 1987, p. 54).

A nyak ékszerei közé egyetlen, erősen sérült, vízszintesen gerezdelt testü üveggyöngyként értelmezhető töredéket sorolhatunk az S 679 sírból.

\section{VISELETI ELEMEK}

A temetőrészlet három sírja tartalmazott viseletre utaló leleteket (fülesgombok, övveretek, ruhaveretek, csatok).

Fülesgombok az S 489 és az S 679 sírokból kerültek elö, összesen öt darab. Az S 489-es sír gombjai azonos típusba tartoznak: mindhárom példány bronz, két félből álló, üreges, amelyeken a fül egy gyürüs taggal csatlakozik a gombhoz. Az S 679 gombjai két különböző típust képviselnek (8. kép). Az egyik egy tömör, ezüstözött, gömb alakú, míg a másik két félből összeillesztett, díszítetlen, bronz példány.

A felső ruházat összefogása a gombokon kívül övvel történhetett. Erre a lelőhelyünk esetében két temetkezésben maradtak emlékek: egy-egy sírban találtunk csatot és veretként értelmezhető fémlemezt. Az S 407-es sírban a medencecsont alól előkerült veret a négyzetes

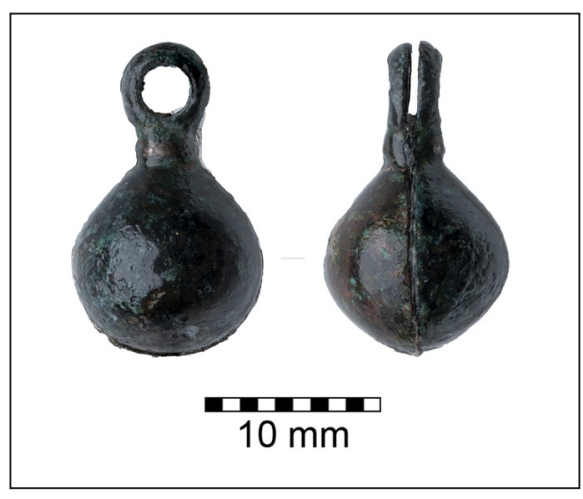

8. kép: Az S 679-es sírból elökerült ezüstözött bronz fülesgomb
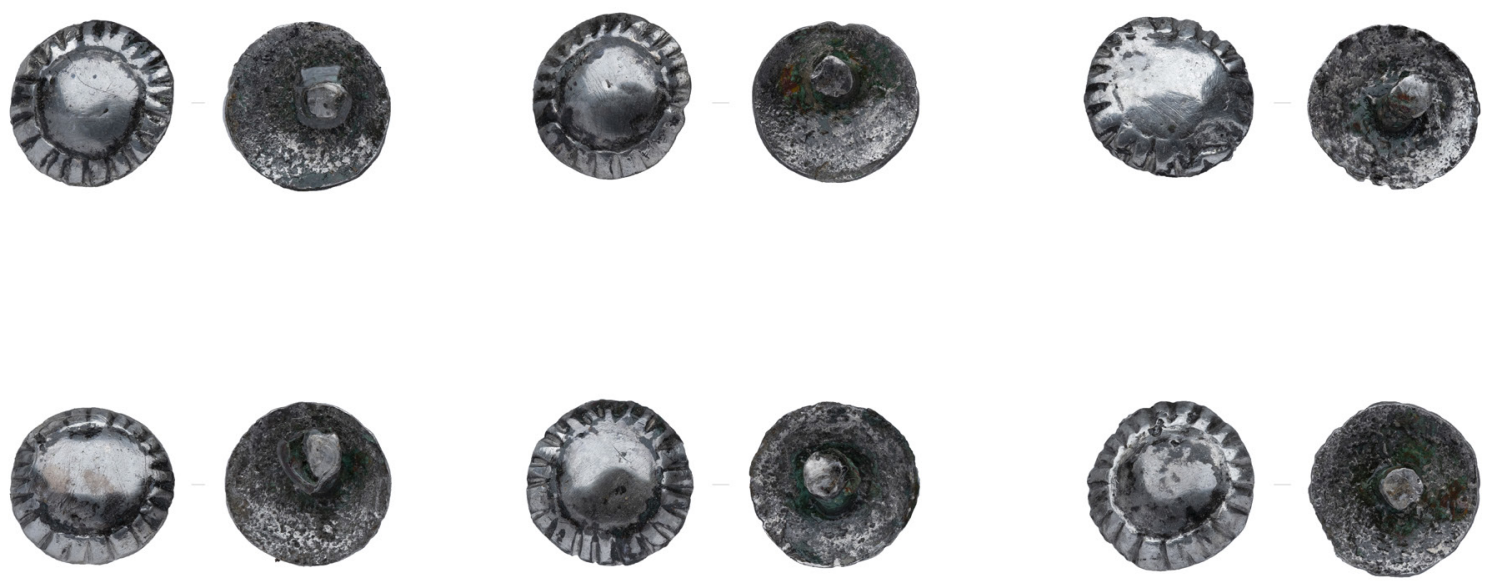

$10 \mathrm{~mm}$ 
Libor Csilla - Takács Richárd • A Hernád-völgy honfoglalói. Részlet egy régió történetéböl

veretek közé tartozik. Ez a verettípus a 10. századra jellemző és elsősorban női temetkezésekből kerül elő (Horváth, 2004, p. 161). Az S 679 sírban egy lekerekített sarkú négyzet alakú vascsatot találtunk. Ezek a csatformák a 10-11. században általánosan elterjedtek voltak, a korszakon belüli finomabb datálásra nem alkalmasak.

Ruhaveretként egyértelműen csak az S 679 sír földjéből származó, hat darab, kör alakú, azonos kinézetü tárgy értelmezhető (9. kép). A félgömb alakú veretek közepén egy gyürű található; a gyürü és a perem közötti területet sugárirányú, bevésett rovátkák töltik ki. A rögzítés nittszeggel történt.

\section{FEGYVERZET}

A fegyverzetet csak az íjászfelszerelés képviseli.

Az S 407-es sírban talált vázcsontok mosása közben került elő egy ovális alakú markolatcsont. Párját nem találtuk meg; a síron belüli pontos helyzete ismeretlen. Az S 489-böl szintén elökerültek egy íj csontszerelékei. Ebben az esetben megtaláltuk az ovális markolatcsontot és az íjkar borításának egy töredékét is.

Szintén az S 489 sírból kerültek elő tegez merevítöpálcáiként értelmezhető vastöredékek, és egy téglalap alakú, domború csont tegezfedél, amihez szintén vaspálcák korrodálódtak (10. kép). A (díszítetlen) csontfedeles tegezek - igaz, nem nagy számban - ismertek a teljes 10. századból, így önmagukban pontosan nem datálhatók (STRAUB, 1999, p. 410). Ezek a tegezek leginkább a Dél-Alföldön koncentrálódnak, a Körösök vonalától északra ritkán kerülnek elő (StRAUB, 1999, 2. kép 1). Lelöhelyünk közelében csak Karos-Eperjesszög II. temetőjéböl ismerünk rá példá-

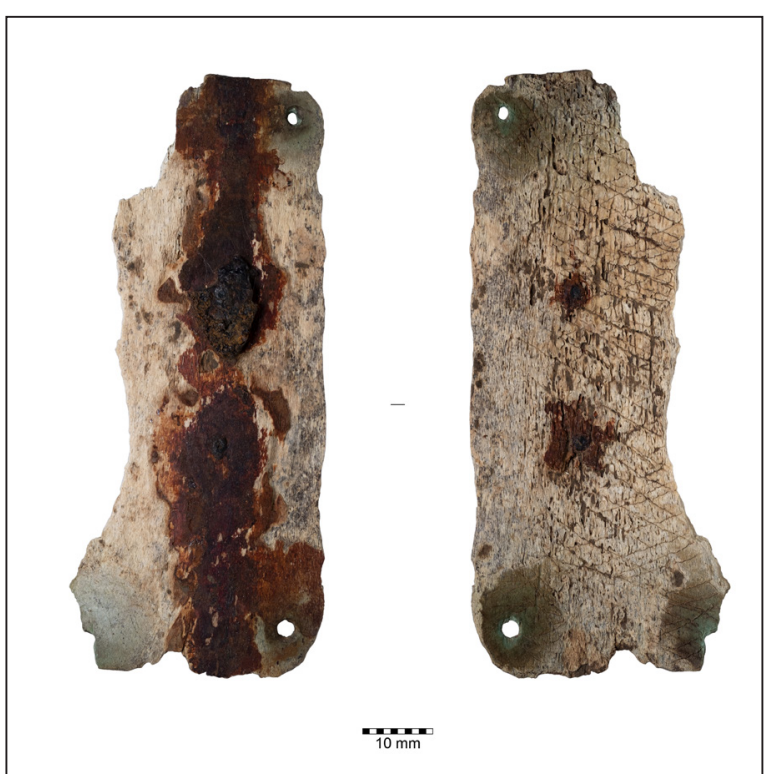

10. kép: Az S 489-es sírból előkerült csont tegezfedél kat (RÉvÉsz, 1996, pp. 18, 27-28, 30).

Az S 679 sírban előkerült egy középső nyélállású vaskés, ami nem értelmezhető egyértelmüen fegyverként, de említésre érdemes tárgy.

\section{HALOTTI OBULUS}

A 10. század folyamán az obulus adás általánosan ismert, de nem túl gyakori jelenség. Az obulus eredeti használatának értelmében a temetés során a halott szájába pénzérmét helyeznek el. A szaleszendi temetőrészletben csak az S 679 sírból kerültek elő obulusként értelmezhető pénzérmék. Mindkét denár a Hugo és II. Lothar uralkodása (931-947) alatt vert, HNI 1/9 típusba tartozik (11-12. kép). Csupán feltételes módban beszélhetünk jelen esetben arról, hogy ez a két érme obulusként került a sírba. Sajnos a bolygatás miatt csu-

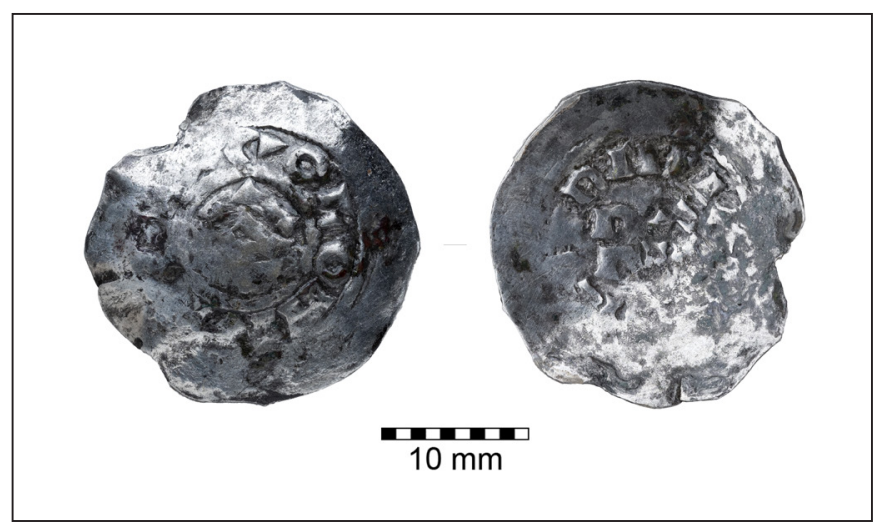

11. kép: Az S 679-es sírból elökerült elsö érme

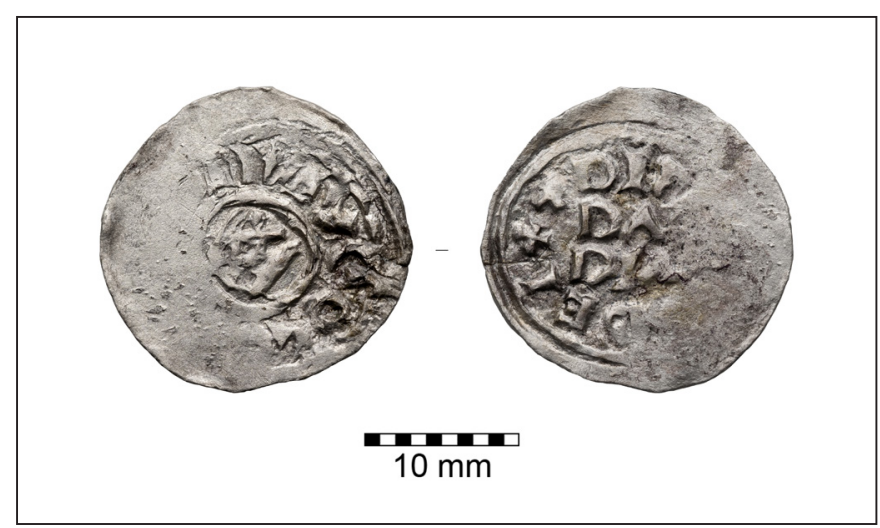

12. kép: Az S 679-es sírból elökerült második érme 
Libor Csilla - Takács Richárd • A Hernád-völgy honfoglalói. Részlet egy régió történetéböl

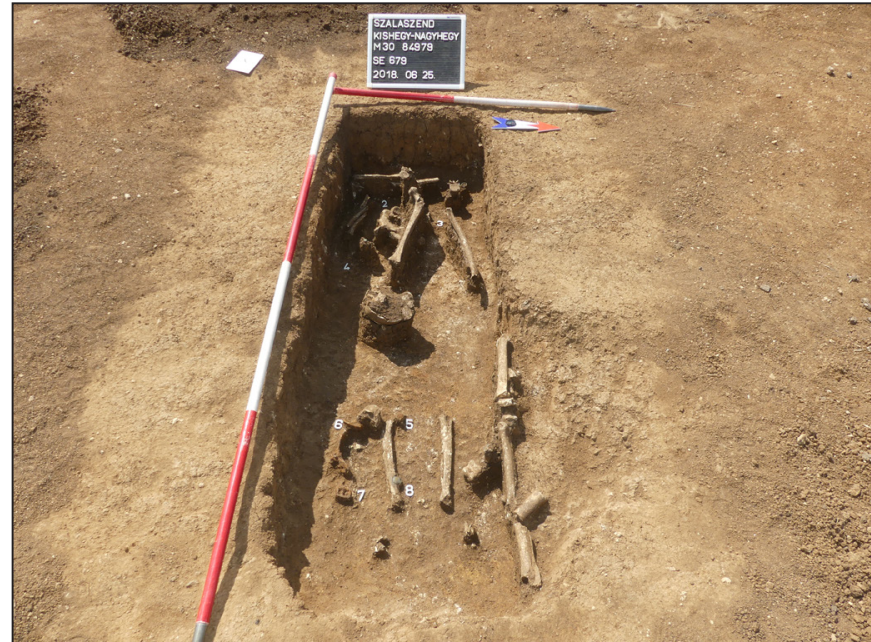

13. kép: Az S 679-es sír sirfotója

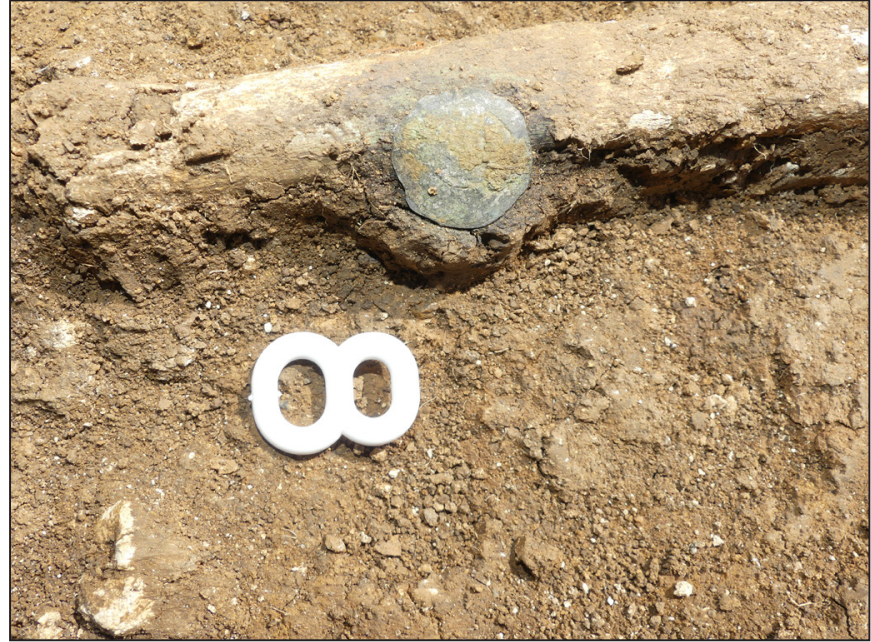

14. kép: A 11-es képen látható érme elökerülési helye

pán az egyik érme helyezkedett el a szemüregben (13. kép), és magát a koponyát sem az anatómiai rendnek megfelelően találtuk meg, mivel a sír közepén, közel medencetájékon volt, fejjel lefelé fordítva. A másik érme a jobb sípcsonton helyezkedett el, a csont középső szakaszánál, a belső oldalához közel. Ez a pozíció magyarázható azzal, hogy amikor a fejet átdobták a sír közepére, akkor az obulus a lábakhoz eshetett. Sajnos erre nincs bizonyítékunk, mindenesetre fontos tény, hogy két darabot találtunk a sírban, és az egyik ténylegesen az egyén szemgödréböl került elö.

\section{ÉRTÉKELÉS}

A temetőrészlet pontos használati ideje a nagyfokú bolygatottság következtében nem állapítható meg. A megmaradt, datáló leletek alapján a lelöhely a 10. század közepére, utolsó harmadára tehető, ugyanakkor a lovastemetkezések és az egyszerű karikaékszerek miatt valószínűleg nem nyúlik bele a 11. századba.

A szalaszendi temetőrészlet sírjai rablottságuk ellenére is sok információval szolgálnak számunkra (például a csontfedeles tegezek elterjedésével kapcsolatos adatokkal), melyekből világossá vált, hogy ez a térség a honfoglalás korában is fontos terület lehetett. Mindezek ellenére a mikrorégió kutatása még korai szakaszban jár, mivel a területről származó 10-11. századi emlékek jelentős része szórvány, vagy nem hiteles ásatásból származó lelet. A most feltárt sírok jól beleillenek a temető tágabb környezetében ismert 10. századi lelöhelyek által alkotott képbe. A temetkezőhely folytatódhatott nyugati irányban; ezt a jövőben talán még lehetőség nyílik kutatni, ám addig is érdemes az M30-as autóút adta lehetőségeket a lehető legjobban kihasználni a mikrorégió történetének pontosabb megismeréséhez.

\section{FELHASZNÁLT IRODALOM}

Dienes, I., 1966.

A honfoglaló magyarok lószerszámának néhány tanulsága. Archaeologiai Értesitö 93, 208-237.

IsTVÁNOVITS, E., 2003.

A rétköz honfoglalás és Árpád-kori emlékanyaga. Régészeti gyüjtemények Nyíregyházán 2. Magyarország honfoglalás és kora Árpád-kori sírleletei 4. Nyíregyháza: Jósa András Múzeum, 2003

HoRváth, C., 2004.

Adatok a honfoglalás kori kő- és üvegbetéttel díszített fegyverek, tarsolyok és veretek kérdésköréhez. Communicationes Archaeologicae Hungariae 2004, 151-171. 
Libor Csilla - Takács Richárd • A Hernád-völgy honfoglalói. Részlet egy régió történetéböl

RÉVÉSz, L., 1996.

A karosi honfoglalás kori temetök. Régészeti adatok a Felsö-Tisza-vidék X. századi történetéhez. Magyarország honfoglalás kori és kor Árpád-kori sírleletei 1. Miskolc: Herman Ottó Múzeum, 1996.

Straub, P., 1999.

A honfoglalás kori tegezcsontok időrendjéhez. Móra Ferenc Múzeum Évkönyve - Studia Archaeologica 5, 409-422.

SZENDREY, Á., 1928.

Az ösmagyar temetkezés. Ethnographia 34, 12-26.

SzŐKE, B. M. \& VÁndor, L., 1987.

Pusztaszentlászló Árpád-kori temetője. Fontes Archaeologici Hungariae. Budapest: Akadémiai Kiadó, 1987.

Tettamanti, S., 1975.

Temetkezési szokások a X-XI. században a Kárpát-medencében. Studia Comitatensia 3, 79-123. 